\title{
Acclimation of Fine Root Systems to Soil Warming: Comparison of an Experimental Setup and a Natural Soil Temperature Gradient
}

\author{
Kaarin Parts, ${ }^{1 *} \odot$ Leho Tedersoo, ${ }^{2}$ Andreas Schindlbacher, ${ }^{3}$ \\ Bjarni D. Sigurdsson, ${ }^{4,5,6}$ Niki I. W. Leblans, ${ }^{7}$ Edda S. Oddsdóttir, ${ }^{8}$ \\ Werner Borken, ${ }^{9}$ and Ivika Ostonen ${ }^{1}$
}

\begin{abstract}
${ }^{1}$ Institute of Ecology and Earth Sciences, University of Tartu, Vanemuise 46, 51014 Tartu, Estonia; ${ }^{2}$ Natural History Museum and Botanical Garden, University of Tartu, Ravila 14a, 50411 Tartu, Estonia; ${ }^{3}$ Department of Forest Ecology, Federal Research and

Training Centre for Forests, Natural Hazards and Landscape - BFW, Vienna, Austria; ${ }^{4}$ Agricultural University of Iceland, 311 Hvanneyri, Borgarnes, Iceland; ${ }^{5}$ CREAF, 08193 Cerdanyola del Vallés, Spain; ${ }^{6}$ CSIC, Global Ecology Unit, CREAF-CSIC, Universitat Autònoma de Barcelona, 08193 Bellaterra, Catalonia, Spain; ${ }^{7}$ Department of Biology, University of Antwerp, Antwerp, Belgium;

${ }^{8}$ Icelandic Forest Research Mógilsá, 162 Reykjavik, Iceland; ${ }^{9}$ Department of Soil Ecology, University of Bayreuth, Bayreuth, Germany
\end{abstract}

\begin{abstract}
Global warming is predicted to impact high-latitude and high-altitude forests severely, jeopardizing their overall functioning and carbon storage, both of which depend on the warming response of tree fine root systems. This paper investigates the effect of soil warming on the biomass, morphology and colonizing ectomycorrhizal community of spruce fine and absorptive fine roots. We compare the responses of spruce roots growing at a man-made long-term soil warming $\left(+4^{\circ} \mathrm{C}\right)$ experiment to results obtained from a geothermal soil temperature gradient $(+1$ to
\end{abstract}

Received 18 April 2018; accepted 24 June 2018 published online 9 July 2018

Electronic supplementary material: The online version of this article (https://doi.org/10.1007/s10021-018-0280-y) contains supplementary material, which is available to authorized users.

Published database given in below link:

https://doi.org/10.5281/zenodo. 1299492.

Author Contributions: IO, AS, BDS and ESO conceived of or designed study, KP, IO, AS, BDS, WB and NIWL performed research, KP and IO analyzed data, IO, LT, BDS and AS contributed new methods or models, and KP wrote the paper.

*Corresponding author; e-mail: kaarinparts@gmail.com $+14^{\circ} \mathrm{C}$ ) extending to the forest die-off edge, to shed light on the generalizability of the warming response and reveal any thresholds in acclimation ability. Trees in warmer soils formed longer and less-branched absorptive roots with higher specific root length and area, and lower root tissue density in both spruce stands, irrespective of warming method and location. Soil warming at the experimental warming site also supported the occurrence of a more varied EcM community and an increase in the abundance of Tomentella spp., indicating a shift in nutrient foraging. Fine and absorptive fine root biomass decreased toward warmer soil, with a sharp reduction occurring between +4 and $+6^{\circ} \mathrm{C}$ from the ambient and leading to the collapse of the fine root system at the geothermal gradient. At the experimental warming site, the applied $+4^{\circ} \mathrm{C}$ warming had no effect on fine and absorptive fine root biomass. The similar fine root responses at the two warming sites suggest that the observations possibly reflect general acclimation patterns in spruce forests to global warming. 
Key words: climate change; specific root length; root tissue density; root traits; fine root biomass; soil temperature gradient; ectomycorrhiza; boreal and temperate forests; Picea sitchensis; Picea abies.

\section{Highlights}

- Soil warming led to a shift in absorptive root morphology and ectomycorrhizal community

- Warming-induced morphological changes in man-made and natural setups were similar

- Collapse of fine root system occurred between +4 and $+6^{\circ} \mathrm{C}$ from the ambient

\section{INTRODUCTION}

The rate of warming in high-latitude and highaltitude forests is predicted to exceed the global average (IPCC 2013). This warming could jeopardize the large amounts of carbon $(C)$ stored in these ecosystems, particularly below-ground (Lal 2005; Prietzel and Christophel 2014; Schindlbacher and others 2015; Melillo and others 2017). The dynamics of soil $\mathrm{C}$ and the resilience of the surrounding forest ecosystems are largely dependent on developments in tree fine root systems and rootassociated fungal communities (Jackson and others 1997; Averill and others 2014; Clemmensen and others 2015), which might contribute as much as $50-70 \%$ of the C stored in boreal forest soils (Clemmensen and others 2013)

Absorptive fine roots (McCormack and others 2015) constitute the most active and predominant part of the fine root system, accounting for more than $75 \%$ of total fine root length and $60 \%$ of total fine root surface (Guo and others 2004). In temperate and boreal forests, absorptive fine roots are prevalently $(90-100 \%)$ colonized by ectomycorrhizal (EcM) fungi (Kraigher and others 2007; Taylor and others 2009), which in turn are associated with rhizosphere bacteria (Frey-Klett and others 2007). These trilateral interactions ensure sufficient root foraging (Ostonen and others 2017). Fine root systems have been shown to respond to changes in the growth environment with great plasticity, either through modifications in fine and absorptive fine root biomass, their absorptive surface per unit of mass (that is, specific root length (SRL) and area (SRA)), branching frequency or shifts in root-associated microbial communities (Finér and others 2007; Richardson and others
2009; Parts and others 2013; Valverde-Barrantes and others 2015; Truu and others 2017). Henceforth, we refer to the entire fine root compartment, which includes primary-structured absorptive and secondary-structured transport roots, as "fine roots" and to the proportion of absorptive fine roots, as "absorptive roots."

Fine and absorptive roots exhibit several architectural and morphological traits that determine nutrient uptake and root functioning, while providing information about root foraging strategies, demographic patterns, soil fertility and plant stress status. For example, higher investment in fine and absorptive root biomass has been shown to be common in nutrient poor forests and associated with the extensive foraging strategy (Helmisaari and others 2007; Ostonen and others 2017). In small-scale nutrient patches, extensive fine root biomass accompanied by increased root tissue density (RTD) and decreased SRL has been reported and associated with the conservative syndrome of forming long-living roots (Valverde-Barrantes and others 2015). On the other hand, high absorptive root SRL and SRA have been thought to reflect the acquisitive or intensive strategy of enhanced resource uptake at lower biomass investments, high root cost efficiency and fast growth (Comas and Eissenstat 2004; Weemstra and others 2016; Ostonen and others 2017). Depending on the circumstances, an increase in SRL and SRA can be viewed either as means of acclimation or serve as indication of plant stress (Rosenvald and others 2011). High SRL and SRA are achieved through a reduction in either RTD or root diameter (D). D has been linked to root survivorship (Wells and Eissenstat 2001; McCormack and others 2012; Weemstra and others 2016), whereas RTD has been reported to increase gradually with root age (Hajek and others 2014). Additionally, RTD is closely associated with soil nutrient availability (Ostonen and others 1999; Kramer-Walter and others 2016).

The identity of the fungal colonizer has a considerable effect on EcM absorptive root diameter, length and mass, thereby also influencing SRA and SRL (van der Heijden and Kuyper 2003; Ostonen and others 2009, 2017; Makita and others 2012), which is why changes in root morphology should not be addressed separately from developments in EcM fungal community. Besides differing in their influence on root growth and shape, EcM fungal taxa exhibit contrasting foraging strategies with varying capacities of enzymatic activities, nutrient uptake and translocation, and maintenance costs to the host plant (Gorissen and Kuyper 2000; Lilleskov and others 2002; Tedersoo and others 2012). 
Therefore, EcM partners have major impact on tree nutrition both directly and indirectly by manipulating root morphology. The different ecological strategies of EcM fungi have been associated with exploration type, based on the amount and differentiation of extramatrical mycelium (Agerer 2001).

The main growth-constraining factors in highlatitude and high-altitude forests are short growing season, low temperatures and for the former, low nitrogen $(\mathrm{N})$ availability (Jandl and Schindlbacher 2014). Moderate warming could therefore initially benefit tree growth through prolongation of the growing season and mobilization of nutrients ( $\mathrm{Xu}$ and others 2012). However, excessive warming can cause depletion of soil water and nutrient supplies and result in retardation of growth and subsequently tree die-off. Presently, the majority of studies have operated with moderate warming levels and knowledge of extreme warming effects is limited (although more extensive warming systems are being developed, Hanson and others 2017). Also, the size and direction of warming effects on root biomass, morphology and the EcM community are highly dependent on nutrient and water availability in the soil (Johnson and others 2006; Leppälammi-Kujansuu and others 2013). In N-deficient boreal forests, experimental soil warming $\left(+5^{\circ} \mathrm{C}\right)$ caused increased fine root production and mortality (King and others 1999; Majdi and Öhrvik 2004; Leppälammi-Kujansuu and others 2014). The possible causes for decreased fine root lifespan include enhanced root metabolism and maintenance respiration, and higher pathogen and herbivore activities (Gill and Jackson 2000; Schindlbacher and others 2009; McCormack and Guo 2014). Significantly higher fine root production and mortality and lower fine root biomass have also been witnessed in open-top chambers, where soil temperature increased only $1.2^{\circ} \mathrm{C}$ (Wan and others 2004), whereas Nishar and others (2017) report a significant decrease in the fine root biomass of the shrub Kunzea tenuicaulis toward warmer soil at a geothermal soil temperature gradient in New Zealand.

In high-latitude N-limited ecosystems, warming has increased EcM mycelial production and community diversity (Clemmensen and others 2006; Treseder and others 2016) and caused a shift toward taxa characterized by abundant extramatrical biomass and large proteolytic capacity and a reduction in taxa with high affinities for labile $\mathrm{N}$ (Deslippe and others 2011). On the other hand, in an alpine forest, where warming resulted in higher inorganic $\mathrm{N}$ availability, an increase in the relative abundance of species that are known to tolerate high levels of $\mathrm{N}$ was reported (Lilleskov and others 2011; Solly and others 2017).

Besides these first indications, our knowledge on fine root adaptation strategies to global warming is still in an emerging state, especially as the number of long-term climate manipulation (warming) experiments is still low. Our objective was to determine the effects of soil warming on: (I) fine root biomass and in particular, the absorptive fine root portion; (II) absorptive root morphology, reflecting individual root level acclimation; (III) the EcM community composition colonizing the spruce roots to understand how fine root foraging adapts to soil warming. Spruce (Picea sitchensis Bong. Carr and Picea abies (L.) Karst.) was selected for this study because of its economical importance and wide distribution in temperate and boreal European forests (Caudullo and others 2016; Houston Durrant and others 2016). At the same time, the shallow root system of spruce species makes them especially vulnerable to changes in soil surface temperature. The responses of spruce roots growing at the man-made long-term soil warming experiment (a Picea abies stand) were compared to results obtained from the geothermal soil temperature gradient extending to the forest die-off edge (a Picea sitchensis stand) to shed light on the generalizability of the reactions, reveal any thresholds in acclimation ability and specify the response curve in relation to the intensity of soil warming.

We hypothesized that soil warming (1) induces a decrease in fine and absorptive root biomass, which concurs with an increase in absorptive root surface (SRA and SRL) and a shift in the community structure of EcM colonizers; (2) root response to warming is similar in the man-made experiment and the natural soil temperature gradient. In addition, we inquired whether any root traits show a sharp change at some point on the temperature gradient or whether the changes are gradual.

\section{Materials ANd Methods}

\section{Study Sites}

The study was carried out on two sites: a manmade soil warming experiment in northern Limestone Alps, close to the village of Achenkirch, Austria; and a natural geothermal gradient (ForHot; www.forhot.is) close to Hveragerði in southern Iceland. Both sites are characterized by a cool humid climate. In Achenkirch, the snow-free period lasts from April/May to November/December and the growing season from May to October. At the ForHot site, snow cover is not permanent 
during winter because of the mild oceanic climate. The soil typically freezes there for at least a couple of months during mid-winter, and the growing season lasts usually from late May to late August. Additional background information about the study sites and the treatments is presented in Tables 1 and 2 and more thoroughly described by Schindlbacher and others $(2015,2009)$ for Achenkirch and by Sigurdsson and others (2016) for ForHot.

\section{Achenkirch Soil Warming Experiment}

The studied forest was dominated by Norway spruce (Picea abies), inter-mixed with European beech (Fagus sylvatica) and silver fir (Abies alba). The amount of ground vegetation was negligible. In 2004, three spots were randomly selected on the site, where a warmed (W) plot and an ambient (A) plot were established. The plots had a size of $2 \times 2$ $\mathrm{m}$ each. Warmed plots were equipped with resistance heating cables $(0.4 \mathrm{~cm}$ diameter, TECUTE- $0.18 \mathrm{Ohm} / \mathrm{m} / \mathrm{UV}$, Etherma, Austria). The cables were buried in 3-cm-deep trenches and had a spacing of 7-8 $\mathrm{cm}$. The soil temperature (ST) of each warmed plot was kept $4^{\circ} \mathrm{C}$ above that of the adjacent ambient plot during the snow-free seasons, starting in spring 2005. On ambient plots, cables were inserted that were not heated, but had inflicted the same soil disturbance as on the warmed plots, although by 2013, the cable effect can be considered irrelevant. Soil temperature, soil moisture, organic $\mathrm{C}$ and total $\mathrm{N}$ concentrations, and soil $\mathrm{pH}$ were measured as described in Schindlbacher and others (2009) and Schnecker and others (2016).

\section{ForHot Natural Soil Temperature Gradient}

On May 29, 2008, an earthquake with a magnitude of 6.3 on the Richter scale occurred in southern Iceland (Halldórsson and Sigbjörnsson 2009). The earthquake affected geothermal systems close to its epicenter and one such system at Reykir moved to a previously unwarmed area (Porbjörnsson and others 2009; Sigurdsson and others 2016), where the new geothermal bedrock channels resulted in increasing temperature in the soil above by radiative heating ( $\mathrm{O}^{\prime}$ Gorman and others 2014). The recently warmed area is covered by an unthinned Sitka spruce forest (Picea sitchensis, provenances Seward and Homer from Alaska) that was planted in 1966-1967.

In autumn 2012, twenty-five permanent experimental plots were established on five replicate transects in the stand (Figure S1). The transects were about $50 \mathrm{~m}$ in length and ranged from ambient soil temperature to about $+10^{\circ} \mathrm{C}$. The location of the plots was chosen aiming for the long-term warming levels (WLs) of about $0,+1$, $+3,+5$ and $+10^{\circ} \mathrm{C}$ warming (hereafter called levels A (unwarmed ambient), B, C, D and E, respectively), although the realized annual temperature means were slightly lower (Table 2; Sigurdsson and others 2016). Owing to the geothermal origin of soil warming, temperature also increased toward the deeper soil on average $2^{\circ} \mathrm{C}$ per depth interval $(0-5,5-10$ and $10-20 \mathrm{~cm}$; Figures 1 and S2). Ground vegetation proliferated only starting from D or E plots, which was close to the warming-induced die-off edge in the spruce stand (Figure Sl; O'Gorman and others 2014).

Table 1. Background Information About the Study Sites

\begin{tabular}{|c|c|c|}
\hline Site (tree species) & Achenkirch (Picea abies) & ForHot (Picea sitchensis) \\
\hline Location & $47.581^{\circ} \mathrm{N}, 11.639^{\circ} \mathrm{E}$ & $64.008^{\circ} \mathrm{N}, 21.178^{\circ} \mathrm{W}$ \\
\hline Elevation, $m$ a.s.l. & 910 & $83-168$ \\
\hline Mean annual temperature, ${ }^{\circ} \mathrm{C}$ & $6.9^{\mathrm{a}}$ & $5.2^{\mathrm{b}}$ \\
\hline Mean annual precipitation, $\mathrm{mm}$ & $1506^{\mathrm{a}}$ & $1457^{\mathrm{b}}$ \\
\hline Stand age & 130 & 50 \\
\hline Soil type ${ }^{c}$ & Chromic Cambisol & Silandic Andosol \\
\hline Bedrock & Dolomite & Volcanic (basalt) \\
\hline Stand basal area ${ }^{\mathrm{d}}, \mathrm{m}^{2} \mathrm{ha}^{-1}$ & 35 & 49 \\
\hline Stand density ${ }^{\mathrm{d}}$, trees ha ${ }^{-1}$ & 487 & 4461 \\
\hline \multicolumn{3}{|c|}{ 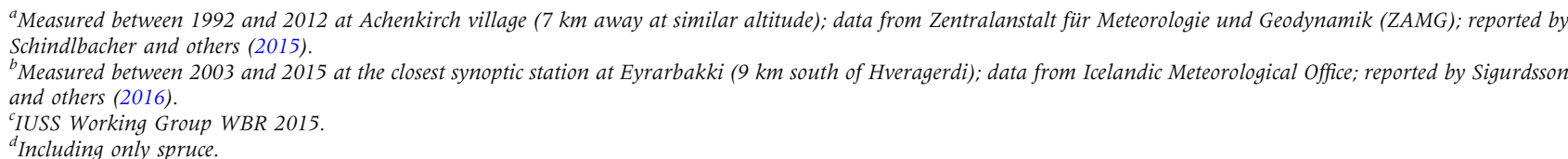 } \\
\hline
\end{tabular}


Table 2. Main Site and Soil Characteristics per Treatment in 2013

\begin{tabular}{|c|c|c|c|c|c|c|c|}
\hline $\begin{array}{l}\text { Site, treatment } \\
\text { (mean } 2013 \\
\text { Warming le- } \\
\left.\text { vels }^{\mathrm{a}}, \Delta \mathrm{T}\right)\end{array}$ & $\begin{array}{l}\text { Average soil } \\
\text { temperature during } \\
\text { vegetation period }{ }^{\mathrm{ab}} \text {, } \\
{ }^{\circ} \mathrm{C}(\Delta \mathrm{T})\end{array}$ & $\begin{array}{l}\text { Soil } \\
\text { temperature } \\
\text { during } \\
\text { sampling, }{ }^{\circ} \mathrm{C} \\
(\Delta \mathrm{T})^{\mathrm{C}}\end{array}$ & $\begin{array}{l}\text { Stand } \\
\text { basal } \\
\text { area, } \\
\mathrm{m}^{2} \mathrm{ha}^{-1}\end{array}$ & $\begin{array}{l}\text { Topsoil } \\
\mathrm{C} / \mathrm{N} \\
\text { ratio }\end{array}$ & $\begin{array}{l}\text { Topsoil } \mathrm{NO}_{3}^{-} \\
\text {availability, } \mu \mathrm{g} \\
10 \mathrm{~cm}^{-2} \\
89 \text { days }^{-1 \mathrm{~d}}\end{array}$ & $\begin{array}{l}\text { Volumetric } \\
\text { water } \\
\text { content, \% }{ }^{\mathrm{e}}\end{array}$ & $\mathrm{pH}-{ }^{\mathrm{f}} \mathrm{H} 2 \mathrm{O}$ \\
\hline $\mathrm{AK} \mathrm{A}$ & 10.5 & 8.0 & 35 & 14.9 & $\mathrm{NE}$ & 47.2 & $\sim 7$ \\
\hline $\mathrm{AK} \mathrm{W}(+4)$ & $14.6(+4.1)$ & $12.1(+4.1)$ & 35 & 16.0 & $\mathrm{NE}$ & 43.5 & $\sim 7$ \\
\hline FH A & 8.2 & 5.8 & 48 & 17.3 & 0.58 & 31.2 & 5.3 \\
\hline $\mathrm{FH} \mathrm{B}(+1)$ & $8.9(+0.7)$ & $7.1(+1.3)$ & 56 & 22.3 & 0.98 & 31.2 & 5.1 \\
\hline $\mathrm{FH} \mathrm{C}(+2)$ & $10.2(+2.0)$ & $7.7(+1.9)$ & 50 & 19.5 & 1.22 & 31.3 & 5.1 \\
\hline $\mathrm{FH} \mathrm{D}(+4)$ & $11.7(+3.5)$ & $8.7(+2.9)$ & 35 & 17.1 & 2.84 & 30.7 & 5.0 \\
\hline FH E $(+8)$ & $15.9(+7.7)$ & $13.7(+7.9)$ & 27 & 16.6 & 82.2 & 45.0 & 5.2 \\
\hline \multicolumn{8}{|c|}{ 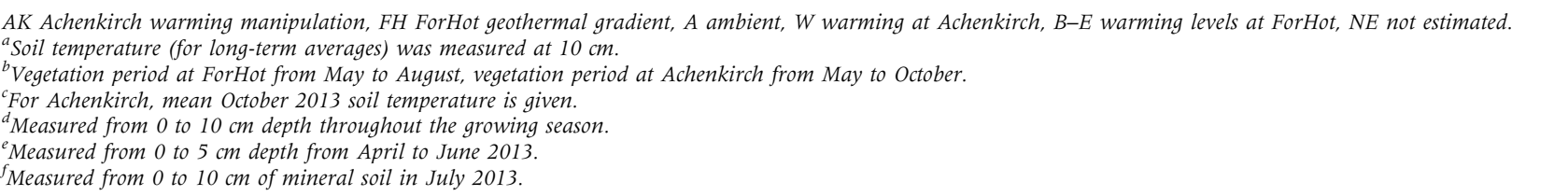 } \\
\hline
\end{tabular}

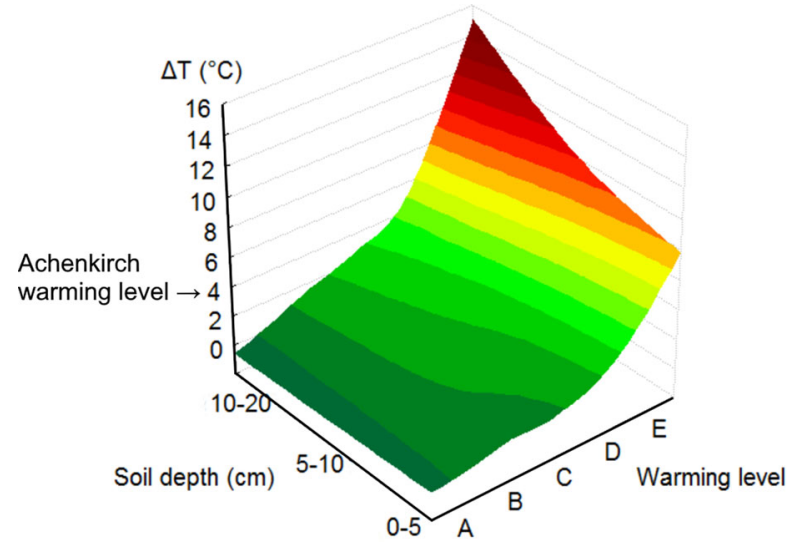

Figure 1. Increase in soil temperature horizontally toward warmer plots $(\mathrm{A} \rightarrow \mathrm{E})$ and depthwise toward warmer soil layers $(0 \rightarrow 20 \mathrm{~cm})$ at the ForHot site. The temperature values presented are not absolute values, but the mean increase in ${ }^{\circ} \mathrm{C}$ from the ambient.

In addition to repeated soil temperature measurements, there were comprehensive data of topsoil macro- and microelement availability (measured with exchange membranes), soil $\mathrm{pH}$ and soil water content taken during the vegetation period of 2013 available for the ForHot gradient (Table 2). For full description of how the measurements were taken, see Sigurdsson and others (2016). Soil organic C and total N concentrations had also been analyzed for the same depth intervals as mentioned above on sieved $(2 \mathrm{~mm})$ and ballmilled samples by dry combustion (Macro Elemental Analyser, model vario MAX CN, Hanau, Germany).
Fine and Absorptive Root Biomass and Morphology

Sampling for absorptive root morphological studies and fine root biomass measurements (FRB, $<2 \mathrm{~mm}$ ) was conducted in September 2013 at the ForHot site and in October 2013 and 2014 at Achenkirch. The samples were collected with a soil corer $8.8 \mathrm{~cm}$ in diameter for $0-10 \mathrm{~cm}$ depth and $3.8 \mathrm{~cm}$ for $10-20 \mathrm{~cm}$ depth at ForHot and $5 \mathrm{~cm}$ in diameter for the whole $0-20 \mathrm{~cm}$ profile at Achenkirch). During root sampling, we also measured soil temperature from three depths $(0-5,5-$ 10 and $10-20 \mathrm{~cm}$ ) in each plot at the ForHot site (Figures 1 and S2).

At ForHot, one soil core was taken per plot (5 cores per warming level, altogether 25 soil cores from the whole experimental area). For morphological studies, the cores were further cut into three soil layers: $0-5,5-10$ and $10-20 \mathrm{~cm}$, because of the approximately $2^{\circ} \mathrm{C}$ increase in soil temperature per layer, as stated above. Each of the 75 samples was then divided into three subsamples, to facilitate work under the microscope. Care was taken to ensure that the subsamples originated from different root fragments. All morphological parameters were measured and calculated for the subsample level, that is, $N=9$ per plot ( 45 per warming level) for morphology and $N=1$ per plot ( 5 per warming level) for biomass estimations at ForHot.

At Achenkirch, five soil cores were taken per plot for morphological analyses (altogether 15 cores per treatment) and three cores per plot for biomass assessment ( 9 cores per treatment). The soil cores 
from Achenkirch were not further divided, because cable placement ensured maximum homogeneity in soil warming (Schindlbacher and others 2009). The samples were again divided into three subsamples (comprising of 6-40 root tips) for morphological measurements, that is, $N=15$ per plot for morphology and $N=3$ per plot for fine root biomass evaluation at Achenkirch.

Spruce roots were separated from understory roots and washed. To determine the number of absorptive root tips per $\mathrm{m}^{2}$, the root tips of two or three fine root fragments (which accounted for at least $1 / 5$ of a sample) were counted. Fine roots were then dried at $65^{\circ} \mathrm{C}$ for $48 \mathrm{~h}$ to constant weight and weighed to $\pm 0.05 \mathrm{mg}$ accuracy. Absorptive fine root biomass (aFRB, $\mathrm{g} \mathrm{m}^{-2}$ ) was calculated by multiplying the mean absorptive root tip weight by the root tip number per $\mathrm{m}^{2}$. The FRB and aFRB were presented per stand basal area (BA) to describe the functional relationship between the above- and below-ground parts of a forest stand.

For morphological studies, first-to-third-order absorptive roots (altogether $>2600$ root tips from the ForHot site and $>1800$ root tips from the Achenkirch site) were analyzed after separating them from the woody fine roots, cleaning and counting under the microscope. The length $\left(L_{S}\right)$, diameter $(D)$ and surface area (SA) of the absorptive roots were measured by the WinRHIZO ${ }^{\text {TM }}$ Pro 2003b image analysis system (Regent Instruments Inc., Quebec). The roots were dried at $70^{\circ} \mathrm{C}$ for $2-$ $3 \mathrm{~h}$ to constant weight and weighed with an accuracy of $\pm 0.05 \mathrm{mg}$. Root tissue density (RTD, $\mathrm{kg} \mathrm{m}^{-3}$ ), specific root area (SRA, $\mathrm{m}^{2} \mathrm{~kg}^{-1}$ ) and specific root length (SRL, $\mathrm{m} \mathrm{g}^{-1}$ ) were calculated as $M_{\mathrm{S}} / V_{\mathrm{S}}, \mathrm{SA} / M_{\mathrm{S}}$ and $L_{\mathrm{S}} / M_{\mathrm{S}}$, respectively, where $V_{\mathrm{S}}$ is the volume, $L_{\mathrm{S}}$ is the length, and $M_{\mathrm{S}}$ is the dry mass of all absorptive roots in a subsample (Ostonen and others 2007b). Branching frequency was expressed as number of root tips per unit of length $\left(B_{\mathrm{L}}\right)$ and unit of weight $\left(B_{\mathrm{W}}\right)$. Mean root tip weight $(W, \mathrm{mg})$ was calculated as the dry mass of all the absorptive roots in a subsample divided by the respective number of root tips. Similarly, mean root tip length $(L, \mathrm{~mm})$ was calculated as the length of all the absorptive roots in a subsample divided by the number of root tips (Ostonen and others 1999).

\section{EcM Fungal Community}

To determine the composition of the EcM fungal community at the Achenkirch site, 30 root samples were collected from the three warmed and the three ambient plots (five root samples per plot as described in the morphology section) in October
2013. The roots of Norway spruce were separated from the roots of understory vegetation and cut into $5 \mathrm{~cm}$ fragments, and two or three fragments from each sample were subjected to morphotyping based on mantle color, texture and the presence of emanating hyphae and rhizomorphs, as described in Agerer (1991). The relative abundance of each morphotype was estimated, and all the morphotypes were classified into exploration types based on visual observation. Categorization into exploration types was verified, if possible, using the relevant literature (Agerer 2006; the DEEMY information system). At least two individual root tips of each morphotype per sample were immersed into CTAB lysis buffer [100mM Tris-HCI ( $\mathrm{pH} 8.0$ ), 1.4 M NaCl, 20mMEDTA, $2 \%$ cetyl-trimethyl-ammonium-bromide] and maintained at room temperature until molecular analyses. One or two representative root tips of each morphotype per sample were subjected to DNA analysis. Fungal taxa were identified by use of sequence analysis of the nuclear rDNA internal transcriber spacer (ITS) region. The DNA was extracted using a Qiagen DNeasy 96 Plant Kit (Qiagen, Crawley, UK) according to the manufacturer's instructions. Primers, PCR conditions, product purification, sequencing and sequence processing are described in Tedersoo and others (2010). Sequence processing was carried out in Sequencher 4.0 (GeneCodes Corp., Ann Arbor, MI, USA). Sequences were assigned to operational taxonomic units (OTUs) based on a $97.0 \%$ ITS barcoding threshold (Tedersoo and others 2003). In order to identify the EcM fungi and possible contaminants, representative sequences of each OTU were subjected to a megablast search against International Nucleotide Sequence Databases (INSD) and UNITE (Abarenkov and others 2010), a "species hypothesis" code (an $\mathrm{SH}$ code) was assigned to the sequences with more than $97 \%$ identity over the blast alignment (Kõljalg and others 2013) and deposited under accessions UDB034264-UDB034324. The above-described separation into morphotypes before sequencing served our aim to identify dominating root colonizers and shifts in their proportions, while we acknowledge that this method underestimates the true OTU richness at Achenkirch. Fungal community composition was not assessed at ForHot.

\section{Statistical Analyses}

Statistical analyses were carried out using STATISTICA 7.1 (StatSoft 2005), PERMDISP (Anderson 2004), CANOCO (ter Braak and Šmilauer 2002) and EstimateS 9.1.0 (Colwell 2013) programs. The 
sample size for analyses carried out with absorptive and fine root biomass was 25 (plot level) for ForHot and 18 (3 samples per plot) for Achenkirch. All analyses for morphology were done on the subsample level $(N=187$ for ForHot and $N=90$ for Achenkirch), besides partial correlations and multiple regressions performed between absorptive root morphology, fine root biomass and soil properties of the ForHot site, which were done on the plot level $(N=22)$ and in the $0-10 \mathrm{~cm}$ depth. Although at ForHot 25 plots were sampled, there were not enough living absorptive roots present in three $\mathrm{E}$ plots for morphological measurements, which decreased sample size for morphological analyses on the plot level to 22. For testing the effect of warming on the abundances of specific EcM genera or exploration types at Achenkirch, analyses were carried out on the sample level $(N=29,4-5$ samples per plot). The value of $\alpha=0.05$ was used as the significance level for all the analyses.

Absorptive root variables were checked for normality using the Kolmogorov-Smirnov test. The effect of warming on absorptive root morphological traits was checked with the $t$ test at the Achenkirch site and using simple linear regression analysis and one-way ANOVA on the ForHot soil temperature gradient. General linear models (type III decomposition) were used to affirm that experimental plots did not have any temperature-independent effect on absorptive root morphology at the ForHot site. After confirming that our manually measured soil temperatures correlated highly with the soil temperature means of the vegetation period and of the whole year of 2013 (Sigurdsson and others 2016; Figure S2, Tables 2 and S3), we used the manually measured soil temperature values from the different soil depth intervals for root morphological analyses, as these values depicted the surrounding conditions during root sampling most precisely.

The effect of warming on fine and absorptive root biomass was checked with the $t$ test (Achenkirch data) and simple linear regression analysis (ForHot data). The warming response of FRB/BA, aFRB/BA and RTD was modeled by the Gompertz function, which was fitted on the average biomass values of each temperature elevation step (calculated from the average vegetation period soil temperatures and rounded to whole numbers).

Redundancy analysis (RDA) (CANOCO program; ter Braak and Šmilauer 2002) was used to visualize relationships between absorptive root morphological characteristics and soil temperature on both experimental sites. The significance of RDA results was tested with the Monte Carlo permutation procedure in CANOCO. In the ForHot fine root biomass regression analyses, we used soil temperature averages of the 2013 vegetation period taken from Sigurdsson and others (2016).

To determine which soil properties influenced absorptive root morphology and fine root biomass in addition to soil temperature at ForHot, partial correlations were examined and all soil parameters that correlated with a given root trait with a significance of $p<0.1$ were included in stepwise multiple regression analyses.

For the EcM community analyses, OTU accumulation (rarefaction) curves and the minimum richness estimators, Chaol, Jackknifel and ACE were calculated. These functions were used to evaluate the sufficiency of sample size and to estimate the proportion of unseen OTUs at the site. When analyzing the effect of soil temperature on the EcM community, all singletons (that is, OTUs present only in one sample) were excluded from analysis, besides for estimating the OTU richness and the Shannon diversity indices. To evaluate the effect of warming and illustrate the dissimilarities in fungal communities (OTU relative abundance), the canonical correspondence analysis (CCA) was employed in CANOCO. The Monte Carlo permutation test was used to decide whether soil temperature had a significant effect on the EcM community composition. The differences in colonization percentages of dominant genera and exploration types between the treatments were checked with the Mann-Whitney $U$ Test. The centroids and the dispersions of the two fungal communities were compared using PERMDISP (Anderson 2001). Differences in OTU richness and Shannon diversity indices between the treatments were tested with the Mann-Whitney $U$ test.

\section{RESULTS}

\section{Soil Warming Effects on Fine and Absorptive Root Biomass}

At the ForHot site, soil warming reduced both fine root biomass (FRB) and absorptive fine root biomass (aFRB) significantly from $753 \pm 171$ (mean \pm SE) and $100 \pm 28 \mathrm{~g} \mathrm{~m}^{-2}$ at the ambient level, respectively, to $50 \pm 27$ and $8 \pm 7 \mathrm{~g} \mathrm{~m}^{-2}$ in the warmest plots $\left(\mathrm{E} ;+8^{\circ} \mathrm{C}\right)$, respectively $\left(R^{2}\right.$ varied from 0.17 to $0.42, \mathrm{p}$ varied from $<0.001$ to $<0.05$; Table S1 and S3). At Achenkirch, no significant temperature effect on neither FRB nor aFRB was revealed, although there was a similar trend of smaller biomass values in warmed plots: mean ambient FRB was $451 \pm 94( \pm \mathrm{SE}) \mathrm{g} \mathrm{m}^{-2}$ 
and aFRB was $134 \pm 23 \mathrm{~g} \mathrm{~m}^{-2}$, mean warming FRB was $392 \pm 87 \mathrm{~g} \mathrm{~m}^{-2}$ and aFRB was $113 \pm 38 \mathrm{~g} \mathrm{~m}^{-2}$. The proportion of absorptive roots among fine roots fluctuated insignificantly along the soil temperature gradient, the means of the warming levels ranging from 0.14 to 0.25 in ForHot and 0.29-0.36 in Achenkirch.

According to the Gompertz function, a sharp decline in FRB/BA started slightly below $+4^{\circ} \mathrm{C}$ (D plots), followed by a rapid decrease in aFRB/BA from $+4^{\circ} \mathrm{C}$ onwards and had reached a plateau by $+6^{\circ} \mathrm{C}$ (E plots), where spruces could not sustain sufficient fine and absorptive root biomass anymore (Figure 2), suggesting a threshold value of $+4^{\circ} \mathrm{C}$ in warming endurance at ForHot. In respect of above-ground growth, stand basal area followed a similar reduction starting from $+3^{\circ} \mathrm{C}$ onwards, which was due to increased tree mortality (Table 2).

Regarding correlations between fine and absorptive root biomass and morphology, both FRB/BA and aFRB/BA were most strongly correlated with root tissue density (RTD) at ForHot $\left(R^{2}=0.51\right.$ for $\mathrm{FRB} / \mathrm{BA}$ and $R^{2}=0.40$ for aFRB/BA, $p<0.001 ;$ Table S3). The decrease in RTD started at about $+6^{\circ} \mathrm{C}$ onwards (that is, E plots), whereas the response of other morphological root parameters (SRL, SRA, $L$ and $B_{\mathrm{L}}$ ) to soil warming was more gradual and no abrupt changes could be distinguished (discussed below). At Achenkirch, FRB/BA was most strongly correlated with root tip weight (W) $\left(R^{2}=0.88, p<0.01\right)$ and aFRB/BA to specific root length $(\mathrm{SRL})\left(R^{2}=0.77, p<0.05\right)$.

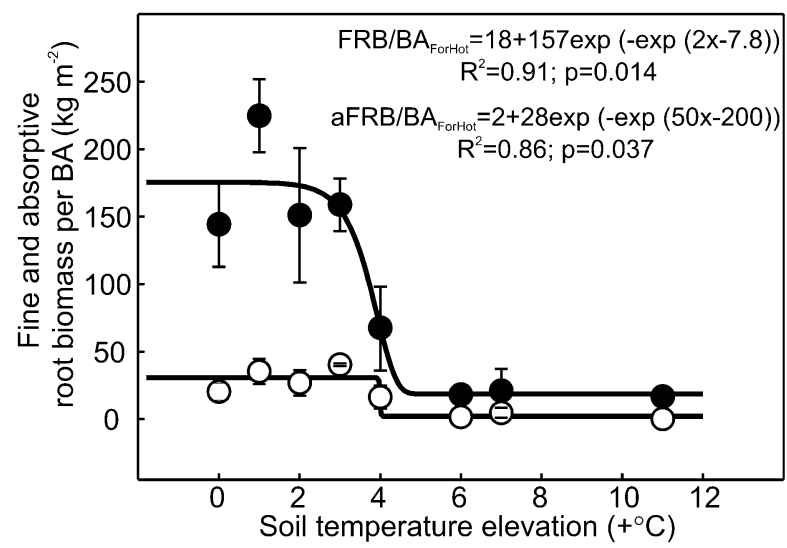

Figure 2. The effect of soil warming on fine (filled circles) and absorptive root biomass (open circles) per stand basal area $\left(\mathrm{kg} \mathrm{m}^{-2}\right.$ for both) at the ForHot soil temperature gradient (means $\pm \mathrm{SE}, N=8$ ). The soil temperature elevations for the ForHot site are calculated from the average soil temperatures of the 2013 vegetation period.
Other soil properties besides temperature that significantly influenced FRB and aFRB (both per $\mathrm{BA}$ and stand area) in the $0-10 \mathrm{~cm}$ depth at ForHot were soil P, Fe, water content and soil pH (Table S5 regression results).

\section{Soil Warming Effects on Absorptive Root Morphology}

Soil warming significantly affected absorptive root morphology at both sites and in the same direction: in warmed soils, absorptive roots had greater length $(L)$, specific root length (SRL), specific root area (SRA), but lower RTD and branching frequency per unit of length $\left(B_{\mathrm{L}}\right)$ (Achenkirch: $p$ varied from $<0.001$ to $<0.01$; ForHot: $R^{2}$ varied from 0.38 to $0.70, p$ from $<0.01$ to $<0.0001$ ) (Figures 3 and S3, Table S1). At Achenkirch, absorptive root diameter (D) was significantly larger in ambient plots, which was partly because of certain EcM colonizers present in ambient plots that form especially large morphotypes (Lactarius scrobiculatus). At ForHot, we did not detect a significant warming effect on root diameter.

At both sites, branching, root tip length and weight (W) experienced the largest variation among the morphological traits (CV varied from 47 to 27), followed by SRL and SRA (CV from 29 to 16). RTD and D varied the least (CV from 15 to 14).

Compared to root morphology, the effects of warming were largest for FRB/BA and aFRB/BA in the warmest plots (E), which was due to the pau-

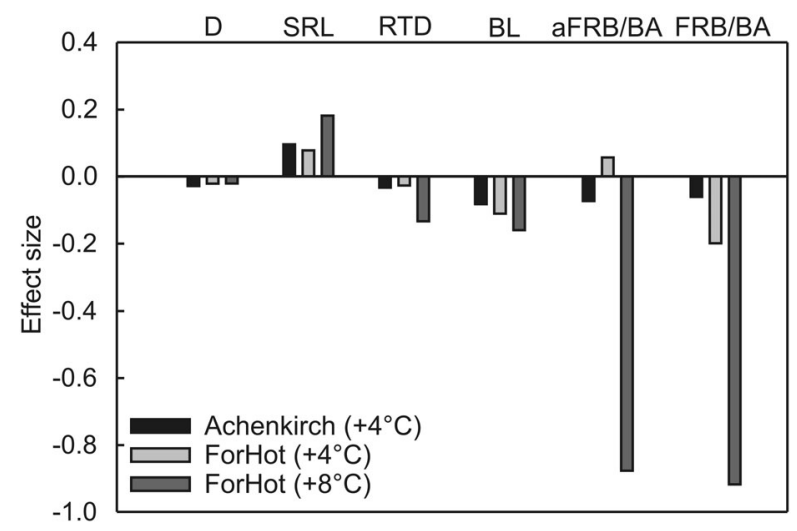

Figure 3. The effect sizes (magnitude of response to soil warming presented in $\log$ scale) of absorptive root morphological parameters and fine and absorptive root biomass at the Achenkirch and ForHot sites. $D$ absorptive root diameter $(\mathrm{mm}), S R L$ specific root length $\left(\mathrm{m} \mathrm{g}^{-1}\right)$, $R T D$ root tissue density $\left(\mathrm{kg} \mathrm{m}^{-3}\right), B_{L}$ branching per unit of length (no $\mathrm{mm}^{-1}$ ), aFRB/BA absorptive root biomass per stand basal area $\left(\mathrm{kg} \mathrm{m}^{-2}\right), F R B / B A$ fine root biomass per stand basal area $\left(\mathrm{kg} \mathrm{m}^{-2}\right)$. 
city of roots there, illustrating the proximity of the die-off edge (Figure 3).

At the ForHot site, the warming response of absorptive RTD, L, W and their reciprocals- $B_{\mathrm{L}}$ and $B_{\mathrm{W}}$-varied with soil depth (Figure 4, Table S1). In the upper part of our studied profile, which experienced more moderate soil temperature elevations, warming reduced root tip proliferation (that is, decreased $B_{L}$ and increased $L$ ), while RTD remained unchanged. At the same time, in the deeper soil that experienced most intense warming (D and $\mathrm{E}$ plots), root shape remained unchanged, while RTD decreased. Absorptive root weight and $\mathrm{B}_{\mathrm{W}}$ had no overall significant response to warming at ForHot, because counterdirectional changes in different soil depths canceled each other out (Figure 4).

At ForHot, soil depth also had a significant independent (not temperature associated) effect on absorptive root morphology, with the decrease in
RTD and branching frequency (both per length and weight) and the increase in SRA and $\mathrm{W}$ toward deeper soil layers (GLM type III SS; $p<0.05$ ).

At the ForHot site, soil moisture and total N, $\mathrm{NO}_{3}{ }^{-}, \mathrm{Mg}, \mathrm{K}$ and $\mathrm{Al}$ concentrations significantly correlated with soil temperature and absorptive root morphology (Table S2). Nevertheless, soil temperature was the prime predictor of variance for SRA, SRL, $L$ and $B_{\mathrm{L}}$, as the correlations between the above-mentioned soil chemical components and root morphological parameters were not significant, when the effect of soil temperature was excluded. Also, soil temperature was the first component in the multiple regression models for these parameters. For RTD, other soil characteristics that appeared in the regression model in addition to soil temperature were soil $\mathrm{C} / \mathrm{N}$ ratio, $\mathrm{pH}$ and $\mathrm{K}$ concentration. The variance in absorptive root diameter related most strongly to variation in soil
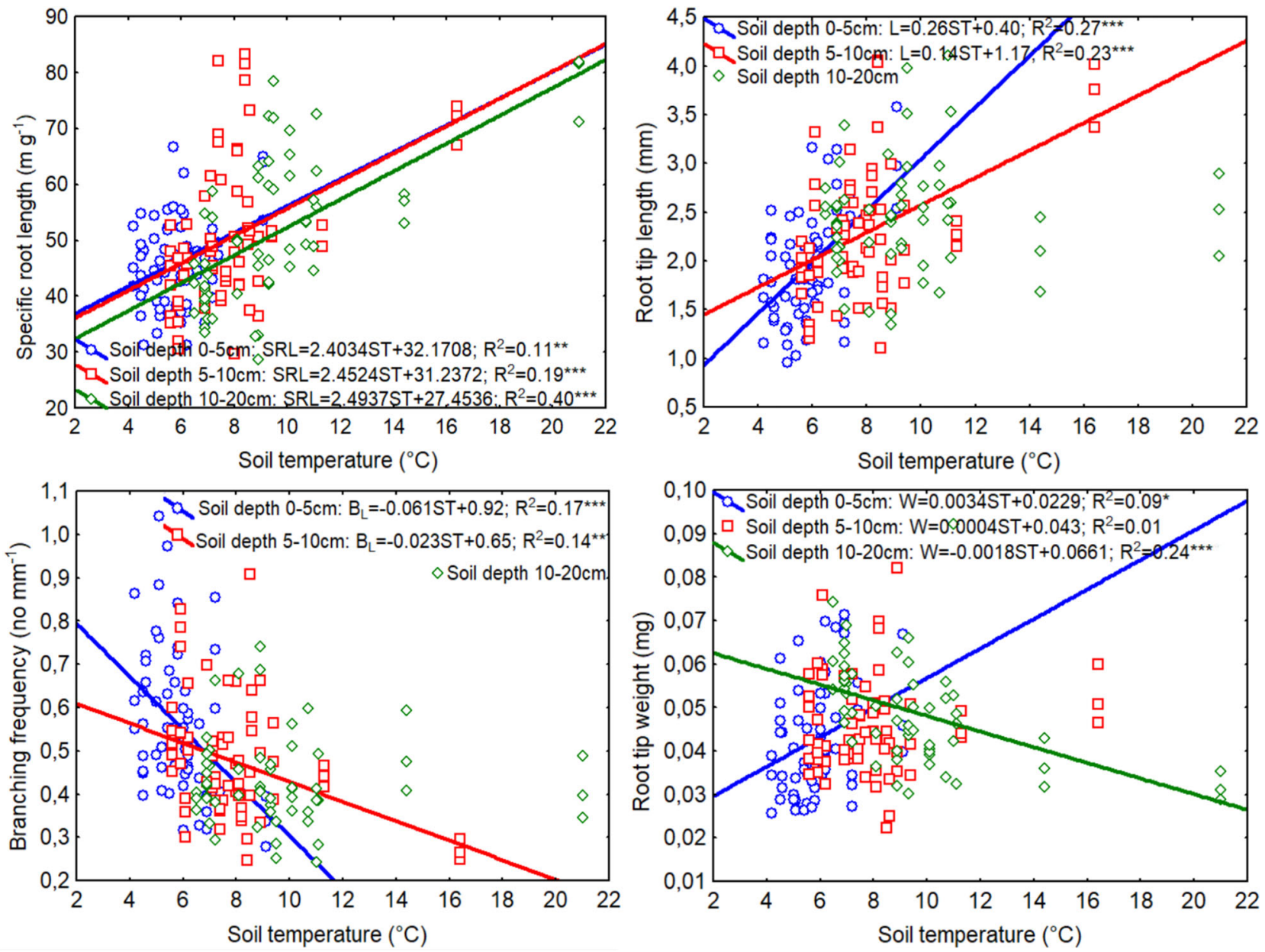

Figure 4. The effect of soil temperature on root morphology in different soil depths at ForHot. ${ }^{*} p<0.05 ;{ }^{*} p<0.01$; $* * * p<0.001$. ST soil temperature, SRL specific root length, $L$ root tip length, $B_{L}$ branching frequency per length, $W$ root tip weight. 
$\mathrm{Al}, \mathrm{K}, \mathrm{Mn}$ and $\mathrm{P}$ concentrations, but not soil temperature (see Table S4 for regression results).

\section{Soil Warming Effects on the EcM Fungal Community}

At the Achenkirch site, sequence analysis revealed 61 ectomycorrhizal fungal OTUs (operational taxonomic units), 52 of which were assigned to predefined SHs (species hypothesis, the proxy for species; see Kõljalg and others 2013) at 97\% sequence similarity level (Table S6). Of these 61 OTUs, 40 occurred in only one sample. Altogether, the OTU richness of control plots was 33 (including 19 singletons) and 41 in warmed plots (21 singletons). Minimum richness estimates for the whole site ranged from 63 (ACE) to 129 (Jackknife2) (Figure S4). However, the large proportion of single occurrences and the fact that neither the rarefaction curve nor the minimum richness estimate curves approached an asymptote suggest underestimation of the true OTU richness at the site.

Overall, the most frequent OTUs were Cenococcum geophilum (SH196545.06FU), Tomentella sp (SH219860.06FU) and Inocybe nitidiuscula (SH236998.06FU). The 61 OTUs belonged to 15 EcM fungal lineages. The /tomentella-thelephora was the most OTU-rich lineage-represented by Tomentella spp., which was significantly more abundant in the warmed plots in terms of overall colonization percentage (Figure 5; $p=0.029$, Mann-Whitney $U$ test). The Tomentella genus was the only group where a significant difference between the treatments was found.

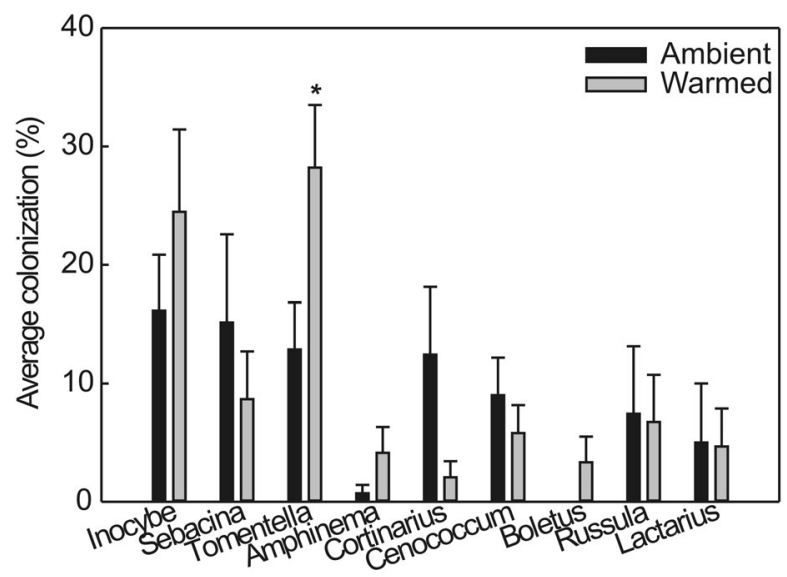

Figure 5. The average colonization percentages of dominant genera in warmed and ambient plots at the Achenkirch site. ${ }^{*} p<0.05$; Mann-Whitney $U$ test. Whiskers signify standard errors.
Morphotypes forming long-distance exploration type (represented by Boletus luridus) were present only in the warmed plots, although in low abundance (Figure 5). There was a trend of larger colonization percentages of contact, short- and medium-distance smooth exploration types in warmed plots, owing to the larger abundance of Tomentella spp., and smaller colonization percentage of medium fringe type in warmed plots, albeit no significant differences between the abundances of the exploration types.

Warming did, however, clearly affects the EcM fungal community structure (CCA of non-singleton OTUs, $p<0.01$; Figure 6 ). The EcM community of warmed $(\mathrm{W})$ plots was more variable than that of the ambient plots $(p<0.01$; PERMDISP), that is, the average distances of OTUs from the group centroid were significantly larger in warmed plots.

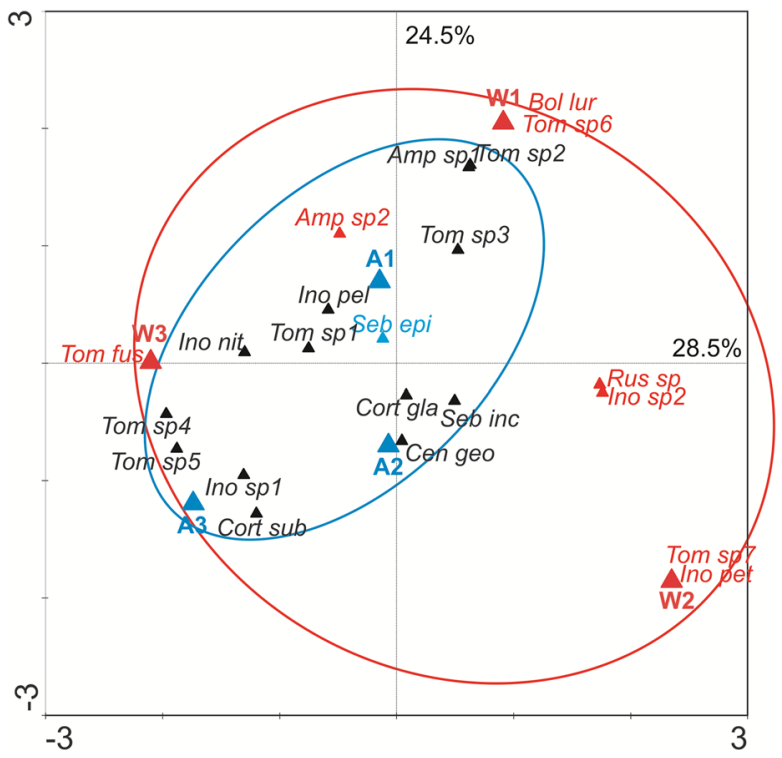

Figure 6. The species-environmental variables biplot of canonical correspondence analysis (CCA), which illustrates the effect of warming on the EcM fungal community (singletons excluded) (Monte Carlo permutation test, $p<0.01)$. Altogether, the plots explained $87 \%$ of variation in the EcM community structure. Red font color signifies SHs that were found only in warmed plots, and blue font color represents SHs present only in the ambient plots. The black SHs were present in both treatments. Large triangles depict the experimental plots. $W$ warming, $A$ ambient, Cen geo Cenococcum geophilum, Ino pet Inocybe petiginosa, Ino pel Inocybe pelargonium, Ino nit Inocybe nitidiuscula, Ino $s p$ Inocybe sp., Bol lur Boletus luridus, Tom fus Tomentella fuscocinerea, Tom sp Tomentella sp., Cort sub Cortinarius subsertipes, Cort gla Cortinarius glaucopus var olivaceus, Seb epi Sebacina epigaea, Seb inc Sebacina incrustans, Amp sp Amphinema sp., Rus sp Russula sp. 
At the same time, there were no significant differences in Shannon diversity indices nor cumulative species richness between the treatments (Figure S5).

\section{Discussion}

This study is the first to compare the effects of soil warming on fine root traits in a man-made experiment (Achenkirch: 9 years of warming) and along a natural soil temperature gradient (ForHot: 6 years of warming). Root system acclimations were viewed simultaneously on different organizational levels: fine and absorptive fine root biomass, absorptive root morphology and the colonizing EcM community. Spruces in warmer soils formed longer and less-branched absorptive roots with higher specific root length and area, and lower root tissue density -a morphological response, which was uniform both at the 47-year-old Sitka spruce stand and the 130-year-old Norway spruce alpine forest, irrespective of warming method and location (Figures 3, 4 and S3). Artificial $+4^{\circ} \mathrm{C}$ warming also supported the occurrence of a more varied EcM community and an increase in the abundance of Tomentella spp. at Achenkirch, indicating a shift in nutrient foraging (Figures 5 and 6). Soil warming led spruces to grow less fine and absorptive root biomass, with a significant decline occurring between +4 and $+6^{\circ} \mathrm{C}$ from the ambient and leading to the collapse of the fine root system at the ForHot site (Figure 2).

At the ForHot geothermal gradient, approximately $+4^{\circ} \mathrm{C}$ from the ambient emerged as a threshold in soil warming endurance, from which onwards Sitka spruces could not sustain sufficient

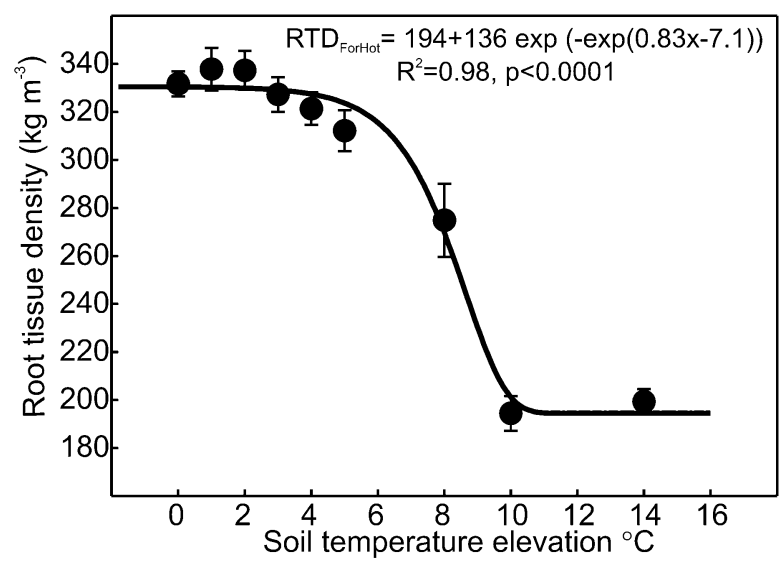

Figure 7. Dynamics of root tissue density (RTD) along the ForHot soil temperature gradient. Means $( \pm \mathrm{SE}$, $N=9$ ) of the whole $0-20 \mathrm{~cm}$ profile were plotted against soil temperature elevations measured during sampling. levels of neither absorptive nor fine root biomass per stand basal area. Regarding above-ground growth at the ForHot gradient, warming induced a rapid decrease in living spruce basal area from $+3^{\circ} \mathrm{C}$, which was due to increased tree mortality. On absorptive root level, root tissue density followed a similar decreasing pattern as fine and absorptive root biomass (Figure 7) and could be indicative of faster root turnover as estimated by W. Borken and others (unpublished data) for Achenkirch, based on ${ }^{14} \mathrm{C}$ signatures. Other soil warming studies also report a decrease in fine root biomass and/or an increase in fine root mortality in warmed soils (Majdi and Öhrvik 2004; Wan and others 2004; Nishar and others 2017), agreeing with our findings.

The decline in fine root biomass between +4 and $+6^{\circ} \mathrm{C}$ might partly explain the absence of a significant biomass response at the Achenkirch site, where the warming level was $+4^{\circ} \mathrm{C}$ above the ambient. At ForHot, there were also no significant differences in fine and absorptive root biomass between the ambient and $\mathrm{D}$ plots $\left(+4^{\circ} \mathrm{C}\right)$ yet. The other possible reason arises from the experimental setup at Achenkirch, where only parts of the individual tree fine root system were exposed to warming, which again demonstrates the sensitivity of absorptive root morphology compared to fine root biomass in responding to environmental changes of small spatial scales. Warming experiments that have reported no effect on fine root production or standing crop, also operated with low temperature elevations, which might explain the lack of response (in addition to nutrient limitation) (Johnson and others 2006; Rinnan and others 2007; Xu and others 2012). As emphasized by Beier and others (2012), a limitation of manipulation experiments is that they rarely apply such extreme treatment levels that lead to ecosystem collapse, whereas the geothermal warming gradient allowed us to pinpoint the mortality threshold of Sitka spruce.

Our results from the soil temperature gradient demonstrate the sensitivity of absorptive root morphology, which responded already to low temperature elevations, compared to more delayed changes in fine and absorptive root biomass. In contrast to RTD, which had significantly decreased at $+4^{\circ} \mathrm{C}$ at Achenkirch and started declining from $+6^{\circ} \mathrm{C}$ onwards at ForHot, significant changes in the other studied morphological parameters (SRL, SRA, $L$ and $\left.B_{\mathrm{L}}\right)$ appeared already from lower warming levels $\left(+3^{\circ} \mathrm{C}\right.$ onwards). We attribute the decrease in $B_{\mathrm{L}}$ and increase in $L$ to diminished root tip proliferation, while the reduction in RTD suggests re- 
duced lifetime of absorptive roots, but also higher metabolic activity (Wahl and Ryser 2000; Ostonen and others 2011; Hajek and others 2014). Therefore, considering SRL and SRA as stress indicators is quite appropriate, at least in relation to the extreme temperature increases experienced at the ForHot gradient. In Achenkirch, similar changes in root morphology correspond to a previously measured increase in microbial stress biomarkers and enhanced metabolic activity (Schindlbacher and others 2011; Liu and others 2017). Co-occurring shifts in absorptive root morphology and rhizosphere microbes have also been shown for birch forests in other climate change simulations (Ostonen and others 2017; Truu and others 2017).

The fact that the above-described morphological differences were evident even after 9 years of warming in a mature forest, suggests persistent change. The morphological parameters exhibiting largest variation for spruce were root branching (per length and weight) followed by absorptive root length, agreeing with the observations of Ostonen and others (2013), who consider high plasticity to reflect higher relevance in the acclimation process.

Leppälammi-Kujansuu and others (2013) also reported an increase in SRL with warming, while RTD decreased and D increased only when warming was accompanied by fertilization in the boreal forest of Flakaliden. Extensive association between RTD and absorptive root diameter, on the one hand, and soil nutrient availability, on the other hand, was evident also at the ForHot site, which distinguished these parameters from the other morphological traits that were influenced by mainly soil temperature. RTD of Norway spruce has been shown to be more sensitive to soil nutrients than other morphological parameters, decreasing toward soils of higher fertility (Ostonen and others 1999, 2007a).

The $+4^{\circ} \mathrm{C}$ increase in soil temperature at the Achenkirch site led to the formation of a more varied EcM community and a significant increase in the colonization of Tomentella spp. in warmed plots-a genus characterized by contact, short- or medium-distance smooth exploration type specialized for nutrient uptake in close vicinity of the roots and an affinity toward labile inorganic forms of nitrogen (Agerer 2001; Cox and others 2010; Kranabetter and others 2015). Because Achenkirch is a $\mathrm{N}$-rich site with high $\mathrm{N}$ deposition, soil warming did not result in any significant differences in soil $\mathrm{N}$ availability (ammonium, nitrate, free amino acid), mineralization or microbial $\mathrm{N}$ between the treatments (Schindlbacher and others 2015; Schnecker and others 2016). Therefore, nitrogen demand can be ruled out in explaining the shift in the fungal community. Instead, the need for other nutrients $(\mathrm{P}, \mathrm{K})$ might have been driving the changes in the EcM community.

Nutrient cycling was presumably faster in the warmed plots at Achenkirch because of intensified fine root turnover (W. Borken and others, unpublished data). Tomentella spp. have been demonstrated to exhibit high activities of cellobiohydrolase, $\beta$-glucosidase and laccase, but also produce acid phosphatase and leucine aminopeptidase (the latter at high $\mathrm{pH}$ ), the amount varying with species, habitat patch, soil horizon and pH (Courty and others 2005; Buée and others 2007; Tedersoo and others 2012). These enzymes are essential in fresh litter degradation and phosphorus acquisition. Tomentella spp. also have high chitinase activities, indicating their ability to degrade saprotrophic fungal tissues for obtaining nutrients (Courty and others 2005; Buée and others 2007). Indeed, significantly higher $\beta$-glucosidase activity, although lower chitinase and leucine aminopeptidase activities have been recorded at the warmed soils of Achenkirch (Schindlbacher and others 2015).

Contrary to our EcM community study conducted at a temperate alpine forest, soil warming at sub-arctic Iceland showed no significant influence on total (Amphinema dominated) fungal community or basidiomycete EcM community composition in incubated mesh bags, according to an earlier study within the same Sitka spruce stand at ForHot (Rosenstock and others 2018). However, they found a significant influence of soil warming on saprotrophic fungal community composition and observed an increase in the abundance of ascomycetous EcM fungi with soil warming. This increase was mainly through changes in the ascomycetes Wilcoxina rehmii and Trichophaea hybrida, which responded positively to warming above ca. $2.5^{\circ} \mathrm{C}$. It has been proposed that the contrasting findings of warming experiments from different ecosystems might not only be caused by variation in soil nutrient form and quantity (being more concentrated into organic form in the arctic), but also differences in soil drought-risk, host species and photosynthetic performance (Cox and others 2010; Lilleskov and others 2011; Pold and DeAngelis 2013; Fernandez and others 2017). Moreover, the numerous biotic and abiotic factors could be simultaneously selecting for taxa with contrasting foraging strategies, which provide complementarity in accessing different resources and coping with different environmental stresses at the same time (reviewed by Courty and others 2010). 
In this study, we joined forces and assessed fine root traits at the man-made soil warming experiment in Achenkirch, where soil was heated via buried cables, and the geothermal soil temperature gradient experiment of ForHot. Artificial soil warming experiments enable us to study any ecosystem (or soil type) of interest and identify causal effects. At the same time, the amount of treatment levels and the spatial and temporal span are usually limited, which prevents the detection of more complex reactions. Also at Achenkirch, only parts of the individual tree fine root system are exposed to warming, which potentially enables unwarmed parts of the root system to compensate for any resource imbalances. Geothermal gradients, on the other hand, allow us to investigate large and gradual temperature increases over relatively small distances, while keeping other confounding environmental factors (climate, elevation, soil type) unchanged. Their large temperature ranges encompass the entire set of climate change predictions, which helps to reveal the shape of the warming response and potential thresholds in acclimation ability (Leblans and others 2017). However, geothermal studies are confined to volcanic environments. The main limitation of both the warming-cable method and geothermal gradients is that they do not imitate global warming to the full, as heat originates from the ground, leaving the air mostly unwarmed ( $\mathrm{O}^{\prime}$ Gorman and others 2014; Leblans 2016).

We conclude that soil warming affected all organizational levels of tree fine root systems, and results obtained from an experimental setup proved to be similar to developments on a natural soil warming gradient. The hypotheses found confirmation-soil warming caused a shift toward the intensive strategy of nutrient foraging (substantial decline in fine and absorptive root biomass complemented with morphological acclimation and associated shift in colonizing EcM community) before the fine root system collapsed. It needs to be emphasized that, in both experiments, warming was restricted to soil, whereas above-ground tree biomass was exposed to ambient air temperatures (and ambient atmospheric $\mathrm{CO}_{2}$ concentrations). Accordingly, the real fine root responses to global change are likely more complex; for example, they could be additionally triggered by increasing labile C flow from above- to below-ground (Norby and Luo 2004) or changes in soil nutrition (Peñuelas and others 2013; Niu and others 2016). Nevertheless, the similar fine root responses at the two warming sites, which were situated in different climate zones and stocked with different spruce species, suggest that the observations are likely to reflect general acclimation patterns to global warming.

\section{ACKNOWLEDGEMENTS}

We thank Krista Lõhmus for valuable discussions, Kessy Abarenkov for guidance with uploading the EcM fungal sequences, and Aale Puri, Aulis Puri, Laura Soon and Marta Arula for assistance in the laboratory. We acknowledge the EU through the European Regional Development Fund (Center of Excellence ENVIRON and EcolChange), the Estonian Ministry of Education, Research projects IUT2-16, IUT34-9 and Lydia and Felix Krabi Scholarship Fund for financial support. We are very grateful to ExpeER for financing the field work of Kaarin Parts and analyses of EcM fungal community samples at the Achenkirch experimental area. This work contributes to the Icelandic ForHotForest Project (IRF Fund, No. 163272-051), the CAR-ES Nordic Network, the ClimMani (ES1308) and the Biolink COST Actions (FP1305).

\section{Compliance with Ethical Standards}

Conflict of interest The authors declare that they have no conflict of interest.

\section{REFERENCES}

Abarenkov K, Nilsson RH, Larsson KH, Alexander IJ, Eberhardt U, Erland S, Høiland K, Kjøller R, Larsson E, Pennanen T, Sen $\mathrm{R}$, Taylor AFS, Tedersoo L, Ursing BM, Vralstad T, Liimatainen K, Peintner U, Kõljalg U. 2010. The UNITE database for molecular identification of fungi-recent updates and future perspectives. New Phytol 186:281-5.

Agerer R. 1991. Characterization of ectomycorrhiza. In: Norris JR, Read DJ, Varma AK, Eds. Techniques for the study of mycorrhiza. London: Academic Press. p 25-73.

Agerer R. 2001. Exploration types of ectomycorrhizae A proposal to classify ectomycorrhizal mycelial systems according to their patterns of differentiation and putative ecological importance. Mycorrhiza 11:107-14.

Agerer R. 2006. Fungal relationships and structural identity of their ectomycorrhizae. Mycol Prog 5:67-107.

Anderson MJ. 2001. A new method for non parametric multivariate analysis of variance. Austral Ecology 26:32-46.

Anderson MJ. 2004. PERMDISP: a FORTRAN computer program for permutational analysis of multivariate dispersions (for any two-factor ANOVA design) using permutation tests. Department of Statistics, University of Auckland, New Zealand.

Averill C, Turner BL, Finzi AC. 2014. Mycorrhiza-mediated competition between plants and decomposers drives soil carbon storage. Nature 505:543-5.

Beier C, Beierkuhnlein C, Wohlgemuth T, Penuelas J, Emmett B, Körner C, de Boeck H, Christensen JH, Leuzinger S, Janssens IA, Hansen K. 2012. Precipitation manipulation experi- 
ments—challenges and recommendations for the future. Ecol Lett 15:899-911.

Buée M, Courty PE, Mignot D, Garbaye J. 2007. Soil niche effect on species diversity and catabolic activities in an ectomycorrhizal fungal community. Soil Biol Biochem 39:1947-55.

Caudullo G, Tinner W, de Rigo D. 2016. Picea abies in Europe: distribution, habitat, usage and threats. In: San-Miguel-Ayanz J, de Rigo D, Caudullo G, Houston Durrant T, Mauri A, Eds. European atlas of forest tree species. Luxembourg: Publ. Off. EU. p e012300+.

Clemmensen KE, Bahr A, Ovaskainen O, Dahlberg A, Ekblad A, Wallander H, Stenlid J, Finlay RD, Wardle DA, Lindahl BD. 2013. Roots and associated fungi drive long-term carbon sequestration in boreal forest. Science 339:1615-18.

Clemmensen KE, Finlay RD, Dahlberg A, Stenlid J, Wardle DA, Lindahl BD. 2015. Carbon sequestration is related to mycorrhizal fungal community shifts during long-term succession in boreal forests. New Phytol 205:1525-36.

Clemmensen KE, Michelsen A, Jonasson S, Shaver GR. 2006. Increased ectomycorrhizal fungal abundance after long-term fertilization and warming of two arctic tundra ecosystems. New Phytol 171:391-404.

Colwell RK. 2013. EstimateS, Version 9.1: statistical estimation of species richness and shared species from samples. http:// viceroy.eeb.uconn.edu/EstimateS/.

Comas LH, Eissenstat DM. 2004. Linking fine root traits to maximum potential growth rate among 11 mature temperate tree species. Funct Ecol 18:388-97.

Courty P-E, Buée M, Diedhiou AG, Frey-Klett P, Le Tacon F, Rineau F, Turpault M-P, Uroz S, Garbaye J. 2010. The role of ectomycorrhizal communities in forest ecosystem processes: new perspectives and emerging concepts. Soil Biol Biochem 42:679-98.

Courty P-E, Pritsch K, Schloter M, Hartmann A, Garbaye J. 2005. Activity profiling of ectomycorrhiza communities in two forest soils using multiple enzymatic tests. New Phytol 167:309-19.

Cox F, Barsoum N, Lilleskov EA, Bidartondo MI. 2010. Nitrogen availability is a primary determinant of conifer mycorrhizas across complex environmental gradients. Ecol Lett 13:110313.

Deslippe JR, Hartmann M, Mohn WW, Simard SW. 2011. Longterm experimental manipulation of climate alters the ectomycorrhizal community of Betula nana in Arctic tundra. Glob Change Biol 17:1625-36.

Fernandez CW, Nguyen NH, Stefanski A, Han Y, Hobbie SE, Montgomery RA, Reich PB, Kennedy PG. 2017. Ectomycorrhizal fungal response to warming is linked to poor host performance at the boreal-temperate ecotone. Glob Change Biol 23:1598-609.

Finér L, Helmisaari H-S, Lõhmus K, Majdi H, Brunner I, Børja I, Eldhuset T, Godbold D, Grebenc T, Konôpka B, Kraigher H, Möttönen M-R, Ohashi M, Oleksyn J, Ostonen I, Uri V, Vanguelova E. 2007. Variation in fine root biomass of three European tree species: Beech (Fagus sylvatica L.), Norway spruce (Picea abies L. Karst.), and Scots pine (Pinus sylvestris L.). Plant Biosyst 141:394-405.

Frey-Klett P, Garbaye J, Tarkka M. 2007. The mycorrhiza helper bacteria revisited. New Phytol 176:22-36.

Gill RA, Jackson RB. 2000. Global patterns of root turnover for terrestrial ecosystems. New Phytol 147:13-31.
Gorissen A, Kuyper TW. 2000. Fungal species-specific responses of ectomycorrhizal Scots pine (Pinus sylvestris) to elevated $\left[\mathrm{CO}_{2}\right]$. New Phytol 146:163-8.

Guo DL, Mitchell RJ, Hendricks JJ. 2004. Fine root branch orders respond differentially to carbon source-sink manipulations in a longleaf pine forest. Oecologia 140:450-7.

Hajek P, Hertel D, Leuschner C. 2014. Root order- and root agedependent response of two poplar species to belowground competition. Plant Soil 377:337-55.

Halldórsson B, Sigbjörnsson R. 2009. The Mw 6.3 Ölfus earthquake at 15:45 UTC on 29 May 2008 in South Iceland: ICEARRAY strong-motion recordings. Soil Dyn Earthq Eng 29:1073-83.

Hanson PJ, Riggs JS, Nettles WR, Phillips JR, Krassovski MB, Hook LA, Gu L, Richardson AD, Aubrecht DM, Ricciuto DM, Warren JM, Barbier C. 2017. Attaining whole-ecosystem warming using air and deep-soil heating methods with an elevated $\mathrm{CO}_{2}$ atmosphere. Biogeosciences 14:861-83.

Helmisaari H-S, Derome J, Nojd P, Kukkola M. 2007. Fine root biomass in relation to site and stand characteristics in Norway spruce and Scots pine stands. Tree Physiol 27:1493-504.

Houston Durrant T, Mauri A, de Rigo D, Caudullo G. 2016. Picea sitchensis in Europe: distribution, habitat, usage and threats. In: San-Miguel-Ayanz J, de Rigo D, Caudullo G, Houston Durrant T, Mauri A, Eds. European atlas of forest tree species. Luxembourg: Publ. Off. EU. p e0137al+.

IPCC. 2013. Climate change 2013: the physical science basis. Contribution of Working Group I to the Fifth Assessment Report of the Intergovernmental Panel on Climate Change. In: Stocker TF, Qin D, Plattner G-K, Tignor M, Allen SK, Boschung J, Nauels A, Xia Y, Bex V, Midgley PM, Eds. Cambridge, United Kingdom and New York, NY, USA: Cambridge University Press.

Jackson RB, Mooney HA, Schulze E-D. 1997. A global budget for fine root biomass, surface area, and nutrient contents. Proc Natl Acad Sci USA 94:7362-6.

Jandl R, Schindlbacher A. 2014. Carbon sequestration in Central European forest ecosystems. In: $\mathrm{CO}_{2}$ sequestration and valorization.

Johnson MG, Rygiewicz PT, Tingey DT, Phillips DL. 2006. Elevated $\mathrm{CO}_{2}$ and elevated temperature have no effect on Douglas-fir fine-root dynamics in nitrogen-poor soil. New Phytol 170:345-56.

King JS, Pregitzer KS, Zak DR. 1999. Clonal variation in aboveand below-ground growth responses of Populus tremuloides Michaux: Influence of soil warming and nutrient availability. Plant Soil 217:119-30.

Kraigher H, Al Sayegh Petkovšek S, Grebenc T, Simončič P. 2007. Types of ectomycorrhiza as pollution stress indicators: case studies in Slovenia. Environ Monit Assess 128:31-45.

Kramer-Walter KR, Bellingham PJ, Millar TR, Smissen RD, Richardson SJ, Laughlin DC. 2016. Root traits are multidimensional: specific root length is independent from root tissue density and the plant economic spectrum. J Ecol 104:1299310

Kranabetter JM, Hawkins BJ, Jones MD, Robbins S, Dyer T, Li T. 2015. Species turnover (beta-diversity) in ectomycorrhizal fungi linked to NH4+ uptake capacity. Mol Ecol 24:59926005 .

Kõljalg U, Nilsson RH, Abarenkov K, Tedersoo L, Taylor AFS, Bahram M, Bates ST, Bruns TD, Bengtsson-Palme J, Callaghan 
TM, Douglas B, Drenkhan T, Eberhardt U, Dueñas M, Grebenc T, Griffith GW, Hartmann M, Kirk PM, Kohout P, Larsson E, Lindahl BD, Lücking R, Martín MP, Matheny PB, Nguyen NH, Niskanen T, Oja J, Peay KG, Peintner U, Peterson M, Põldmaa K, Saag L, Saar I, Schüßler A, Scott JA, Senés C, Smith ME, Suija A, Taylor DL, Telleria MT, Weiss M, Larsson KH. 2013. Towards a unified paradigm for sequence-based identification of fungi. Mol Ecol 22:5271-7.

Lal R. 2005. Forest soils and carbon sequestration. Forest Ecology and Management 220:242-58.

Leblans NIW. 2016. Natural gradients in temperature and nitrogen: Iceland represents a unique environment to clarify long-term global change effects on carbon dynamics.

Leblans NIW, Sigurdsson BD, Vicca S, Fu Y, Penuelas J, Janssens IA. 2017. Phenological responses of Icelandic subarctic grasslands to short-term and long-term natural soil warming. Glob Change Biol 23:4932-45.

Leppälammi-Kujansuu J, Ostonen I, Strömgren M, Nilsson LO, Kleja DB, Sah SP, Helmisaari HS. 2013. Effects of long-term temperature and nutrient manipulation on Norway spruce fine roots and mycelia production. Plant Soil 366:287-303.

Leppälammi-Kujansuu J, Salemaa M, Kleja DB, Linder S, Helmisaari HS. 2014. Fine root turnover and litter production of Norway spruce in a long-term temperature and nutrient manipulation experiment. Plant Soil 374:73-88.

Lilleskov EA, Hobbie EA, Fahey TJ. 2002. Ectomycorrhizal fungal taxa differing in response to nitrogen deposition also differ in pure culture organic nitrogen use and natural abundance of nitrogen isotopes. New Phytol 154:219-31.

Lilleskov EA, Hobbie EA, Horton TR. 2011. Conservation of ectomycorrhizal fungi: exploring the linkages between functional and taxonomic responses to anthropogenic $\mathrm{N}$ deposition. Fungal Ecol 4:174-83.

Liu D, Keiblinger KM, Schindlbacher A, Wegner U, Sun H, Fuchs S, Lassek C, Riedel K, Zechmeister-Boltenstern S. 2017. Microbial functionality as affected by experimental warming of a temperate mountain forest soil-a metaproteomics survey. Appl Soil Ecol 117-118:196-202.

Majdi H, Öhrvik J. 2004. Interactive effects of soil warming and fertilization on root production, mortality, and longevity in a Norway spruce stand in Northern Sweden. Glob Change Biol 10:182-8.

Makita N, Hirano Y, Yamanaka T, Yoshimura K, Kosugi Y. 2012. Ectomycorrhizal-fungal colonization induces physio-morphological changes in Quercus serrata leaves and roots. J Plant Nutr Soil Sci 175:900-6.

McCormack ML, Adams TS, Smithwick EAH, Eissenstat DM. 2012. Predicting fine root lifespan from plant functional traits in temperate trees. New Phytol 195:823-31.

McCormack ML, Dickie IA, Eissenstat DM, Fahey TJ, Fernandez CW, Guo D, Helmisaari HS, Hobbie EA, Iversen CM, Jackson RB, Leppälammi-Kujansuu J, Norby RJ, Phillips RP, Pregitzer KS, Pritchard SG, Rewald B, Zadworny M. 2015. Redefining fine roots improves understanding of below-ground contributions to terrestrial biosphere processes. New Phytol 207:505-18.

McCormack ML, Guo DL. 2014. Impacts of environmental factors on fine root lifespan. Front Plant Sci 5:1-11.

Melillo JM, Frey SD, DeAngelis KM, Werner WJ, Bernard MJ, Bowles FP, Pold G, Knorr MA, Grandy AS. 2017. Long-term pattern and magnitude of soil carbon feedback to the climate system in a warming world. Science 358:101-5.
Nishar A, Bader MK, Gorman EJO, Deng J, Breen B, Leuzinger S. 2017. Temperature effects on biomass and regeneration of vegetation in a geothermal area. Front Plant Sci 8:1-11.

Niu S, Classen AT, Dukes JS, Kardol P, Liu L, Luo Y, Rustad L, Sun J, Tang J, Templer PH, Thomas RQ, Tian D, Vicca S, Wang YP, Xia J, Zaehle S. 2016. Global patterns and substrate-based mechanisms of the terrestrial nitrogen cycle. Ecol Lett 19:697709.

Norby RJ, Luo Y. 2004. Evaluating ecosystem responses to rising atmospheric $\mathrm{CO}_{2}$ and global warming in a multi-factor world. New Phytol 162:281-93.

O'Gorman EJ, Benstead JP, Cross WF, Friberg N, Hood JM, Johnson PW, Sigurdsson BD, Woodward G. 2014. Climate change and geothermal ecosystems: natural laboratories, sentinel systems, and future refugia. Glob Change Biol 20:3291-9.

Ostonen I, Helmisaari H-S, Borken W, Tedersoo L, Kukumägi M, Bahram M, Lindroos A-J, Nöjd P, Uri V, Merilä P, Asi E, Lõhmus K. 2011. Fine root foraging strategies in Norway spruce forests across a European climate gradient. Glob Change Biol 17:3620-32.

Ostonen I, Lõhmus K, Helmisaari H-S, Truu J, Meel S. 2007a. Fine root morphological adaptations in Scots pine, Norway spruce and silver birch along a latitudinal gradient in boreal forests. Tree Physiol 27:1627-34.

Ostonen I, Lõhmus K, Lasn R. 1999. The role of soil conditions in fine root ecomorphology in Norway spruce (Picea abies (L.) Karst.). Plant Soil 208:283-92.

Ostonen I, Püttsepp Ü, Biel C, Alberton O, Bakker MR, Lõhmus K, Majdi H, Metcalfe D, Olsthoorn AFM, Pronk A, Vanguelova E, Weih M, Brunner I. 2007b. Specific root length as an indicator of environmental change. Plant Biosyst 141:426-42.

Ostonen I, Rosenvald K, Helmisaari H-S, Godbold D, Parts K, Uri V, Lõhmus K. 2013. Morphological plasticity of ectomycorrhizal short roots in Betula sp and Picea abies forests across climate and forest succession gradients: its role in changing environments. Front Plant Sci 4:335.

Ostonen I, Tedersoo L, Suvi T, Lõhmus K. 2009. Does a fungal species drive ectomycorrhizal root traits in Alnus spp.? Can J For Res 39:1787-96.

Ostonen I, Truu M, Helmisaari H-S, Lukac M, Borken W, Vanguelova E, Godbold DL, Lõhmus K, Zang U, Tedersoo L, Preem J-K, Rosenvald K, Aosaar J, Armolaitis K, Frey J, Kabral N, Kukumägi M, Leppälammi-Kujansuu J, Lindroos A-J, Merilä P, Napa Ü, Nöjd P, Parts K, Uri V, Varik M, Truu J. 2017. Adaptive root foraging strategies along a boreal-temperate forest gradient. New Phytol 215:977-91.

Parts K, Tedersoo L, Lõhmus K, Kupper P, Rosenvald K, Sõber A, Ostonen I. 2013. Increased air humidity and understory composition shape short root traits and the colonizing ectomycorrhizal fungal community in silver birch stands. For Ecol Manag 310:720-8.

Peñuelas J, Poulter B, Sardans J, Ciais P, Van Der Velde M, Bopp L, Boucher O, Godderis Y, Hinsinger P, Llusia J, Nardin E, Vicca S, Obersteiner M, Janssens IA. 2013. Human-induced nitrogen-phosphorus imbalances alter natural and managed ecosystems across the globe. Nat Commun 4:2934.

Pold G, DeAngelis KM. 2013. Up against the wall: the effects of climate warming on soil microbial diversity and the potential for feedbacks to the carbon cycle. Diversity 5:409-25.

Prietzel J, Christophel D. 2014. Organic carbon stocks in forest soils of the German Alps. Geoderma 221-222:28-39. 
Richardson AE, Barea J-M, McNeill AM, Prigent-Combaret C. 2009. Acquisition of phosphorus and nitrogen in the rhizosphere and plant growth promotion by microorganisms. Plant Soil 321:305-39.

Rinnan R, Michelsen A, Bååth E, Jonasson S. 2007. Fifteen years of climate change manipulations alter soil microbial communities in a subarctic heath ecosystem. Glob Change Biol 13:2839.

Rosenstock NP, Ellström M, Oddsdottir E, Sigurdsson BD, Wallander H. 2018. Carbon sequestration and community composition of ectomycorrhizal fungi across a geothermal warming gradient in an Icelandic spruce forest. Fungal Ecol [Accepted].

Rosenvald K, Ostonen I, Truu M, Truu J, Uri V, Vares A, Lõhmus K. 2011. Fine-root rhizosphere and morphological adaptations to site conditions in interaction with tree mineral nutrition in young silver birch (Betula pendula Roth.) stands. Eur J For Res 130:1055-66.

Schindlbacher A, Rodler A, Kuffner M, Kitzler B, Sessitsch A, Zechmeister-Boltenstern S. 2011. Experimental warming effects on the microbial community of a temperate mountain forest soil. Soil Biol Biochem 43:1417-25.

Schindlbacher A, Schnecker J, Takriti M, Borken W, Wanek W. 2015. Microbial physiology and soil CO2 efflux after 9 years of soil warming in a temperate forest-no indications for thermal adaptations. Glob Change Biol 21:4265-77.

Schindlbacher A, Zechmeister-Boltenstern S, Jandl R. 2009. Carbon losses due to soil warming: do autotrophic and heterotrophic soil respiration respond equally? Glob Change Biol 15:901-13.

Schnecker J, Borken W, Schindlbacher A, Wanek W. 2016. Little effects on soil organic matter chemistry of density fractions after seven years of forest soil warming. Soil Biol Biochem 103:300-7.

Sigurdsson BD, Leblans NIW, Dauwe S, Guðmundsdóttir E, Gundersen P, Gunnarsdóttir GE, Holmstrup M, Ilieva-Makulec K, Kätterer T, Marteinsdóttir B, Maljanen M, Oddsdóttir ES, Ostonen I, Peñuelas J, Poeplau C, Richter A, Sigurðsson P, Van Bodegom P, Wallander H, Weedon J, Janssens I. 2016. Geothermal ecosystems as natural climate change experiments : the ForHot research site in Iceland as a case study. Icelandic Agric Sci 29:53-71.

Solly EF, Lindahl BD, Dawes MA, Peter M, Souza RC, Rixen C, Hagedorn F. 2017. Experimental soil warming shifts the fungal community composition at the alpine treeline. New Phytol 215:766-78.

StatSoft I. 2005. STATISTICA (data analysis software system), version 7.1. Www.statsoft.com

Taylor LL, Leake JR, Quirk J, Hardy K, Banwart SA, Beerling DJ. 2009. Biological weathering and the long-term carbon cycle: integrating mycorrhizal evolution and function into the current paradigm. Geobiology 7:171-91.

Tedersoo L, Kõljalg U, Hallenberg N, Larsson K. 2003. Fine scale distribution of ectomycorrhizal fungi and roots across substrate layers including coarse woody debris in a mixed forest. New Phytol 159:153-65.
Tedersoo L, Naadel T, Bahram M, Pritsch K, Buegger F, Leal M, Kõljalg U, Põldmaa K. 2012. Enzymatic activities and stable isotope patterns of ectomycorrhizal fungi in relation to phylogeny and exploration types in an afrotropical rain forest. New Phytol 195:832-43.

Tedersoo L, Sadam A, Zambrano M, Valencia R, Bahram M. 2010. Low diversity and high host preference of ectomycorrhizal fungi in western Amazonia, a neotropical biodiversity hotspot. ISME J 4:465-71.

ter Braak CJF, Šmilauer P. 2002. CANOCO reference manual and CanoDraw for Windows user's guide: software for canonical community ordination (version 4.5). Microcomputer Power, Ithaca, NY, USA. http: www.pri.wur.nl/uk/prod ucts/canoco/.

Porbjörnsson D, Sæmundsson K, Kristinsson S, Kristjánsson B, Ágústsson K. 2009. Suðurlandsskjálftar 29. maí 2008. Áhrif á grunnvatnsborð, hveravirkni og sprungumyndun [The South Iceland earthquake on 29th of May 2008. Impacts on groundwater levels, activity of geothermal hot-spots and creation of seismic cracks]. Rep. No. ÍSOR-2009/0. Unnið fyrir Orkuveitu Reykjavíkur, Iceland Geosurvey, Reykjavik, Iceland.

Treseder KK, Marusenko Y, Romero-Olivares AL, Maltz MR. 2016. Experimental warming alters potential function of the fungal community in boreal forest. Glob Change Biol 22:3395-404.

Truu M, Ostonen I, Preem J-K, Lõhmus K, Nõlvak H, Ligi T, Rosenvald K, Parts K, Kupper P, Truu J. 2017. Elevated air humidity changes soil bacterial community structure in the silver birch stand. Front Microbiol 8:557.

Valverde-Barrantes OJ, Smemo KA, Feinstein LM, Kershner MW, Blackwood CB. 2015. Aggregated and complementary: symmetric proliferation, overyielding, and mass effects explain fine-root biomass in soil patches in a diverse temperate deciduous forest landscape. New Phytol 205:731-42.

van der Heijden EW, Kuyper TW. 2003. Ecological strategies of ectomycorrhizal fungi of Salix repens: root manipulation versus root replacement. Oikos 103:668-80.

Wahl S, Ryser P. 2000. Root tissue structure is linked to ecological strategies of grasses. New Phytol 148:459-71.

Wan S, Norby RJ, Pregitzer KS, Ledford J, O'Neill EG. 2004. CO enrichment and warming of the atmosphere enhance both productivity and mortality of maple tree fine roots. New Phytol 162:437-46.

Weemstra M, Mommer L, Visser EJW, van Ruijven J, Kuyper TW, Mohren GMJ, Sterck FJ. 2016. Towards a multidimensional root trait framework: a tree root review. New Phytol 211:1159-69.

Wells CE, Eissenstat DM. 2001. Marked differences in survivorship among apple roots of different diameters. Ecology 82:882-92

Xu Z, Yin H, Xiong P, Wan C, Liu Q. 2012. Short-term responses of Picea asperata seedlings of different ages grown in two contrasting forest ecosystems to experimental warming. Environ Exp Botany 77:1-11. 